\title{
Informed Consent Reformulation by Health Personnel in Health Services
}

\author{
Dian Lukita Sari, Arief Suryono, Isharyanto
}

Masters Program in Law, Universitas Sebelas Maret

\begin{abstract}
Background: Informed consent is an approval given after receiving information. The arrangement of informed consent is more emphasized on the medical act, namely the Minister of Health Regulation no. 290 of 2008 on Approval of Medical Measures, whereas in addition to doctors / dentists including health personnel must also obtain the consent of the patient. Article 68 paragraph (6) of Law no. 36 of 2014 on Health Manpower explaines that the procedures for approval of the Health Manpower Act are regulated by Ministerial Regulation, but until now none of it existed. Therefore, it is necessary to reformulate informed consent to provide legal certainty for all health personnel.
\end{abstract}

Subjects and Methods: Normative type study with statute approach that is legislation and conceptual approach, technique of collecting law material with literature study. Technical analysis of legal materials was done by formulating legal principles, formulating legal understanding and formation of legal standards.

Results: Urgency of reformed informed consent in health service action for health personnel viewed from the perspective of legislation that is Law no. 36 Year 2009 on Health, Law no. 44 Year 200 on Hospital, Law no. 36 of 2014 on Health Manpower and Regulation of the Minister of Health RI No. 69 of 2014 on Hospital Obligations and Patient Obligations explained that informed consent is provided by health personnel. Urgency due to social interests in the matter of public security as well as social interests concerning the lives of individuals. Urgency of legal certainty that the law can be implemented properly if there is adequate regulation and equal treatment before the law. Ideal informed consent reform as the implementation of Article 68 paragraph (6) of the Law on Health Manpower needs to re-regulate Regulation of the Minister of Health Number 290 Year 2008 regarding Approval of Medical Measures. Reformulation of preliminary consideration and consideration considering the adjusted development of science as well as legal subjects informed consent uniformed into health personnel.

Conclusions: The urgency of reformulating informed consent is because in the therapeutic agreement, it is the fulfillment of the principle of consensualism in the agreement; for the social interest in public security matters and concerning the lives of individuals and need the latest regulation for legal certainty for all health personnel. Ideal informed consent reform is the needs to reorganize the Approval of Health Personnel Act by substituting Regulation of the Minister of Health No. 290 Year 2008 on Approval of Medical Measures, by changing the subjects for "Health Personnel".

Keywords: informed consent, health service, health personnel.

\section{Correspondence:}

Dian Lukita Sari. Masters Program in Law, Universitas Sebelas Maret, Jl. Ir. Sutami No. 36 A, 57126, Surakarta, Central Java Email: dtiaro2@gmail.com. Mobile: +6285648127557

\section{BACKGROUND}

Health is a human right and one of the elements of welfare that must be realized in accordance with the ideals of the Indonesian nation according to Pancasila and the
Preamble of the Constitution of the Republic of Indonesia Year 1945. This research tries to offer reformulated informed consent in health service action for health workers. Reformulation is concerned with 
the importance of legal certainty for all health personnel who require informed consent to the patient for the actions of the health services provided.

Provision of health services by health personnel can be accepted or rejected by the patient after understanding the information in the informed consent completely. Acceptance or rejection is a form of agreement result, which legally becomes one of the terms of engagement arising from the agreement, so that informed consent or known as the approval term after explanation is needed (Kusmaryanto, 2016). Informed consent has been recognized in Indonesian legislation since 1989 and is conceptually much related to the provisions of the law of engagement in the book III of the Civil Code of the treaty in general.

The regulation on informed consent is more emphasized on the approval of medical act, namely Law Number 29 Year 2004 regarding Medical Practice, in Article 45 paragraph (1) up to paragraph (6) and on the approval of medical act, namely Minister of Health Regulation no. 290 of 2008 on Approval of Medical Measures, whereas in the implementation of health service measures, in addition to doctors / dentists included in the group of health workers must also obtain the consent of the patient.

Article 56 paragraph (1) letter b Law no. 36 Year 2014 on Health Personnel explained that in carrying out the practice, health personnel must obtain an approval from the recipient of health / family services for the action given. Article 68 paragraph (1) of the same law makes it clear that any individual health care action performed by health personnel should be approved. The articles explain that informed consent is not only for medical acts, but for other health personnel. Article 68 Paragraph (6) of the Health Personnel
Law describes the provisions on the procedure for approval of the Health personnel action under the Ministerial Regulation, which until now, there is no specific regulation on the approval of the action of health workers, it is only on the Accord of Medical Measures.

The rules of informed consent law must be based on Law no. Law No. 12 Year 2011 on the Establishment of Laws and Regulations in Article 5 which is the principle of compatibility between types, hirerarchy and material content to be implemented, giving rise to usefulness and usefulness in the life of the community, nation and state and Article 18 that the regulation of informed consent is not only focused on medical acts, for other health personnel, it will be fulfilled one of the legal objectives of legal certainty and material content of the Laws Regulation should reflect the principle of law and order of law. This is because Article 28D Paragraph (1) of the 1945 Constitution stating that "Everyone is entitled to the recognition, guarantee, protection, and legal certainty which is equal to the same treatment before the law."

Based on the explanation above, it is necessary to conduct legal writing under the issue of "Reformulation of Informed Consent in the Action of Health Services for Health Personnel". Problems which are examined including:

1. What is the urgency of reformulating informed consent in the act of health services for health personnel?

2. What is the ideal reformulation of informed consent in the act of health services for health personnel?

\section{SUBJECTS AND METHOD}

The type of normative legal study is study focused on assessing the application of norms or norms in terms of theoretical, 
principle, conception, legal doctrine and the content of positive law rules. Such study can be conducted primarily on primary and secondary legal materials, as long as the materials contain legal principles (Mamudji and Soekanto, 2006). This study used the statute approach.

The first one is the statute approach. This approach is used because the answers to legal research problems will refer to relevant legislation. Researchers will perform activities description, systematization, and interpretation of the law. The legislation is presented as follows:

1. The 1945 Constitution of the State of the Republic of Indonesia;

2. Law Number 29 Year 2004 related to Medical Practice;

3. Law Number 36 Year 2009 related to Health;

4. Law Number 44 Year 2009 related to Hospital;

5. Law Number 38 Year 2014 about nursery;

6. Law Number 12 Year 2011 on the Establishment of Laws and Regulations;

7. Law Number 36 Year 2014 on Health Personnel;

8. Regulation of the Minister of Health Number 290 Year 2008 related to Approval of medical measures;

9. Regulation of the Minister of Health No.17 of 2013 on Amandement of Regulation of the Minister of Health No. HK.0202 / Ministry of Health/ 148/2010 concerning Permission and Implementation of Nurse Practices;

10. Regulation of the Minister of Health No.69 of 2014 on Hospital Liability and Patient Obligations;

11. Regulation of the Minister of Health Number 28 of 2017 concerning License and Implementation of Midwife Practice.
The second one is the conceptual approach. The conceptual approach goes from the views and doctrines that develop in the science of law. The author conducts an inventory of legal concepts relating to health care, informed consent, health personnel, and theory of interests and legal certainty theory. The next process, the authors describe and explain the concepts in order to effectively combined.

The technique of collecting legal materials used in this study was literature study, which is a technique to collect legal materials by reviewing laws and regulations, huku books, legal papers, legal journals, magazines, and newspapers (Waluyo, 2008). The technique of legal material analysis on normative research using library as a source of research data can be done with several stages including (Amminudin and Zainal, 2014) :

1. Formulating legal principles both from social data and from positive written legal data;

2. Formulating legal understanding; and

3. Establishing of legal standards.

\section{RESULTS}

1. The urgency of reinformed consent reform in health service action for health personnel

\section{a. The perspectives of laws and regulations}

Informed consent in the therapeutic agreement is the fulfillment of the principle of consensualism that animates the law of agreement based on the article 1320 Civil Code mentioned that an agreement will occur when both parties reach an agreement. Therapeutic agreements are also called therapeutic contracts known as contracts in health (Salim, 2004). The therapeutic contractual relationship law by the law is interpreted differently although in principle, the therapeutic covenant 
relationship is the same ie the relationship between patients and medical personnel (Wijanarko and Sari, 2014). The importance of informed consent in the act of health services for health personnel because of taking action without the consent of medical action is one of the circumstances that can lead to criminal malpractice due to carelessness (Pakandek, 2010). Description of the urgency of informed consent construction in health service action for health personnel which are based on the perspective of Laws Regulation are presented as follows:

1) Law no.36 Year 2009 related to Health. The arrangement of informed consent in Article 44 paragraph (3), Article 65 paragraph (2), Article 76 point $\mathrm{c}$ and Article 119 paragraph (3);

2) Law no. 44 Year 2009 related to hospital. The arrangement of informed consent in Article 32 letter k, Article 37 paragraph (1) and Article 38 paragraph (2);

3) Law no. 36 Year 2014 related to Health personnel. The arrangement of informed consent in Article 58 paragraph (1) letter b, Article 68 paragraph (1) to (6) and Article 69; and

4) Regulation of the Minister of Health No.69 Year 2014 related to Hospital Obligations and Patient Obligations explained that informed consent is provided by health personnel. The arrangement of informed consent in Article 16 paragraph (2), Article 24 paragraph (2) letter $h$ and Article 24 paragraph (2) letter i.

b. Informed consent in the action of health services for health personnel is associated with the Theory of Law

\section{1) Associated with Interest Theory}

Laws can be used to organize changes in everyday life and in the context of necessity, logical-analytical and abstract laws (pure law). A progressive step is needed to enable the law to organize a change called Pound theory about law as tool of social engineering. There are 3 (three) interest groups namely public interest, social interests (including: a) social interests in general security matters b) in the case of the security of social institutions, c) in regard to public morals, d) concerning the safe guarding of social resources, social progress and f) concerning individual life) (Satjipto, 2013).

The types of interests relating to the reformulation of informed consent in the implementation of health services for health personnel include first, social interests in public security concerning interests in the protection of labor and order, health and safety, security of transactions and income. Informed consent is as a legal protection for health personnel in the event of a malpractice as well as functioning as a security for the patient for the health services he or she receives. Second, the social interest concerning the individual's life is that every human being has basic health rights that include social and individual health. The individual right is the right to self determination, including:

a) Right to agree with the informed consent;

b) Right to have privacy;

c) Right to choose the doctor;

d) Right to reject the informed consent;

e) Right to stop;

f) Right to second opinion;

g) Right to the medical records

Law plays as a means of social engineering, meaningful use of conscious law to achieve the dream (ius constituendum) (Milovanovic, 1994). 


\section{2) Associated with the Theory of Legal Certainty}

Legal certainty is one of the objectives of the law and is a guarantee that the law should be executed in a good or proper way. The law is closely related to the politics of power blowing then that's where the law is docked (Marwan, 2010). Article 6 of Law Number 12 Year 2011 concerning the Establishment of Laws and Regulations states that any material on the content of legislation should be able to achieve the desire in society through legal certainty. Article 28D Paragraph (1) of the 1945 Constitution states that "Everyone is entitled to the recognition, guarantee, protection and legal certainty of justice and equal treatment before the law".

The constitutional norm asserts that as a state based on law, the guarantee of legal certainty for all colors of the state of Indonesia without exception is an absolute right that must be guaranteed and protected by the state. Fair legal certainty is a part of Human Rights. Thus, the law is required to be based on a fair legal certainty (Isharyanto, 2016). Thus, adequate rules on the reformulation of informed consent in health care measures for health personnel are necessary in upholding the rights and duties and equal treatment before the law in all health workers.

2. Ideal Reformulation of Informed Consent in Health Services Action for Health Personnel

\section{a. Law Facts which are related to Informed Consent in Health Services Action for Health Personnel}

Law facts about the ideal informed consent in health services action for health personnel including some aspects. First, on article 5 e of constitution number 12 of 2011 about The Establishment of Legislation Regulations on "Principles of Utilization and Use" that every Legislation was made because it was really needed and useful in regulating the life of society, nation, and state. The law cannot be separated from the knowledge of society and state, therefore, the law need to be learned from the context of implementation in public or social life (Ashofa, 2001).

Second, on article $18 \mathrm{c}$ of constitution number 12 of 2011 about The Establishment of Laws and Regulations that the Planning organization of the constitution design was based on "Other Law Orders". The Establishment of Ministerial Regulation concerning the Approval of Health Personnel Action has been mandated in Article 68 paragraph (6) Number 36 of 2014 about Health Personnel.

Third, it was necessary to evaluate and analyze the existing law regulation, namely Ministry of Health Regulation Number 290 of 2008 concerning Approval of Medical Actions aimed at:

1) The Efforts to synchronize and harmonize the content related to existing law regulations;

2) Avoiding overlapping arrangements, because the need for consistency of laws and rules was a fundamental reason for such evaluations and analyzes;

3) To make arrangements of law regulations to be more integrative, comprehensive, and avoid possible legal conflicts; and

4) Avoiding any resistance or ignorance by the people to the Law Regulations which would be implemented through a judicial review or other resistances (Khopiatuziadah, 2016).

Harmonization was also related to the approach of legislation, and the understanding of the lex specialis derograt legi generali principle was also necessary (Kelsen, 2012). Reformulation of informed consent need to be made to the Ministry of 
Journal of Health Policy and Management (2018), 3(1): 47-55

https://doi.org/10.26911/thejhpm.2018.03.01.07

Health Regulations Number 290 of 2008

about the Approval of Medical Actions

which clearly can be presented in the following table:

Table 1. Reformulation Constructions of Informed Consent in Health Services Action for Health Personnel

\begin{tabular}{|c|c|}
\hline Substance & Existing Conditions \\
\hline $\begin{array}{l}\text { Conside- } \\
\text { rations }\end{array}$ & $\begin{array}{l}\text { That as the implementation of Article } 45 \text { ofFirst, as the implementation of } \\
\text { Constitution Number } 29 \text { of } 2004 \text { on MedicalArticle } 68 \text { Paragraph (6) of Consti- } \\
\text { Practice, it was necessary to re-establish thetution Number } 36 \text { of } 2014 \text { about } \\
\text { Agreement of Medical Actions with the MinistryHealth Personnel, it was necessary } \\
\text { of Health Regulation } \\
\text { to re-arrange the Agreement of } \\
\text { Health Personnel Actions with the } \\
\text { Ministry of Health Regulation; } \\
\text { Second, the development of health } \\
\text { service provision was more com- } \\
\text { plex in terms of number, type, and } \\
\text { form of service; } \\
\text { Third, that Ministry of Health } \\
\text { Regulation Number 290 of 20o8 } \\
\text { about Medical Action Approval } \\
\text { was no longer in accordance with } \\
\text { the development of science and } \\
\text { technology in health. }\end{array}$ \\
\hline
\end{tabular}

Remembering First, Constitution Number 23 of 1992 concern-First, Law Regulation Number 36 the Conside- ing Health (State Gazzete of the Republic ofof 2009 about Health

rations Indonesia of 1992 Number 100, Additional State

Gazzete to the Republic of Indonesia Number

3495);

Second, Government Regulation Number 32 of Second, Law Regulation

1996 about Health Personnel (State Gazzete of Number 36 of 2014 about

1996 Number 39 Additional State Gazzete Health Personnel

Number 3637);

Third, Regulation of the Ministry of HealthThird, Regulation of the Ministry Number 920/Ministry of Health/Regulation/-of Health Number 028 / Ministry XI/1986 about Private Health Services in Medicalof Health / Regulation / I /2011 Field; about Clinic

Fourth, Ministry of Health Regulation NumberFourth, Law Regulation Number 159b/ Ministry of Health/ Regulation/II/ 198844 of 2009 about Hospital

regarding Hospital as lastly changed by the

Judgment of the Ministry of Health and Social

Welfare Number 191/Ministry of Health-Social

Health /SK/II/ 2001 about Amendment of

Ministry of Health Decree Number 157 /Ministry

of Health/ SK/III/1999 on Second Judgment to

Ministry of Health Regulation Number 159b/

Ministry of Health/Regulation/II/1988 regarding

Hospital;

Informed Doctor or Dentist

Consent

It was recommended that the

Subjects terms and subjects of informed consent can be changed into "health personnel" in order to avoid further interpretation.

Source: Primary Law Material, processed by author (2018) 


\section{b. Foundation of Informed Consent Reformulation in Health Service Actions for Health Personnel}

The flow of Utilitarianism was a flow that put the benefit as the main goal of law. Good or bad and fair or not of a law was depending on whether the law gave happiness to human or not (Bertens, $\mathrm{K}$. 1992). In this case, other non-physician or dental health workers should have rights to provide informed consent for the actions of health services provided to the patient, so that there was no difference because all health personnel have the ability to provide health services.

Sociological Jurisprudence that good law must be law which was in accordance with the laws in society. Regulations concerning the approval of health personnel actions were expected to be in accordance with the sociological jurisprudence law that good law must be law that was in accordance with the laws of the community.

Based on the results of this study, it can conclude that:

1. Urgency Reformulations of Informed consent in Health Service Actions for Health Personnel

Proposed reformulation of informed consent in Health Services Action for Health Personnel, for the following reasons: first, the importance of informed consent, because taking an action without the approval of medical action was one of the circumstances that can lead to criminal malpractice due to carelessness. Informed consent in the therapeutic agreement was the fulfillment of the principle of consensualism that inspirited the law agreement. Second, the patients' behalf, informed consent was one of the protection forms on doctors/nurses/midwives/health personnel who perform medical actions on the basis of standard medical profession, however, they may faced the unexpected consequences and considered to be detrimental to other parties, then error medical action was secured under the "risk of treatment" and "error of judment" for the sake of health.

Third, the reformulation of informed consent in health service actions for health personnel fulfilled the social interest in the matter of general security if the malpractice was occurred and also as the safety of the patient for the health services they received. Fourth, it was related to the social interest concerning the life of the individual that every human being has basic health rights covering social and individual health. The right of the individual was the right to self determination, this was the basic right of the individual that came from human rights, one of them was the right to informed consent. Fifth, the medical action performed by health personnel would be better protected, by the existence of adequate rules, it was absolutely necessary in upholding the rights and obligations and everyone has rights to a fair legal certainty and equal treatment for the law.

2. Ideal Reformulations of Informed consent in Health Service Actions for Health Personnel

Reformulation of informed consent in health service actions for health personnel need to be implemented considering the legal norms relating to informed consent which should be made based on the good Principles of Establishment of Law Regulations as regulated in Article 5 of Constitution Number 12 of 2011 about the Establishment of Laws and Regulations, including the principle of compatibility between species, hirerarchy, and material to be implemented, resulting in usefulness in regulating the life of society, nation, and state. Lex specialis derograt legi generali principle also need to be understood. This 
principle refer to two or more law regulations which hirearkically have the same position, but the scope of the content material between the laws and regulations was not the same, which one of them was a special arrangement.

Ideal reformulations of informed consent in health service actions for health personnel as the implementation of Article 68 paragraph (6) of Constitution Number 36 of 2014 about Health Personnel, it was necessary to re-regulate the Regulation of the Ministry of Health Number 290 of 2008 regarding the Approval of Medical Action. Therefore, the subjects in informed consent may be given not only doctors or dentists, but nurses, midwives, and other health personnel.

Based on the results of this study, the author suggests:

\section{For Health Personnel}

Informed consent was needed in carrying out medical action on the patient, and it can be used as a defense against the demands if the unexpected result was arised.

\section{For Law Enforcer}

Revision of Ministry of Health Regulation Number 290 of 2008 about the Approval of Medical Actions into Ministry of Health Regulation concerning the Approval of Health Personnel Actions.

\section{For Patients}

It is expected for the patients to remind health personnel if they have not given the informed consent, because informed consent served as a security for patients on health services.

\section{REFERENCES}

$\overline{\text { Amminudin, Zainal A (2014). Pengantar }}$ Metode Penelitian Hukum. Jakarta: PT. Raja Grafindo.

Bertens K (1992). Ringkasan Sejarah Filsafah. Yogyakarta: Kanisius.

Burhan Ashofa (2001). Metode Penelitian
Hukum. Jakarta: Rineka Cipta.

Constitution of the Republic of Indonesia of 1945 .

Constitution Number 29 of 2004 about Medical Practice;

Constitution Number 36 of 2009 about Health;

Constitution Number 44 of 2009 about Hospital;

Constitution Number 38 of 2014 about Nursing;

Constitution Number 12 of 2011 about the Establishment of Law Regulations;

Constitution Number 36 of 2014 about Health Personnel

Isharyanto (2016). Hukum Pelayanan Kesehatan. Jakarta: Herya Medika.

Kelsen, Hans (2012). Teori Hans Kelsen Tentang Hukum. Jakarta: Konstitusi Pers.

Khopiatuziadah (2016). Evaluasi dan Analisis Peraturan Perundang-Undangan dalam Penyusunan Nasakan Akademik. Jurnal Rechts Vinding Online.

Kusmaryanto CB (2016). Bioetika. Jakarta: Kompas.

Marwan, Awaludin (2010). Teori Hukum Kontemporer Suatu Pengantar Postmoderenisme Hukum. Yogyakarta: Rangkang Education.

Milovanovic, Dragan (1994). A Premier in the Sociology of Law. Newyork: Harrow and Heston Publisher.

Ministry of Health Regulation Number 290 of 2008 about the Approval of Medical Actions.

Ministry of Health Regulation Number 17 of 2013 about the amendment to the regulation of Ministry of Health Number HK.02.02/Ministry of Health/ 148/2010 about Permission and Implementation of Nurse Practice.

Ministry of Health Regulation Number 69 of 2014 about Hospital and Patient Obligations. 
Ministry of Health Regulation Number 28 of 2017 about Permission and Implementation of Midwives Practice.

Pakandek, Adriana (2010). Informed Consent dalam Pelayanan Kesehatan. Jurnal Al-Ilkam, 5(2).

Salim HS (2004). Hukum Kontrak: Teori \& Teknik Penyusunan Kontrak. Jakarta: Sinar Grafika.

Satjipto R (2013). Teori Hukum Strategi
Tertib Manusia Ruang dan Generasi. Yogyakarta: Genta Publising.

Waluyo, Bambang (2008). Penelitian Hukum Dalam Praktek. Jakarta: Sinar Grafika.

Wijanarko B, Sari MP (2014). Tinjauan Yuridis Sahnya Perjanjian Teraputik dan Perlindungan Hukum bagi Pasien. Privat Law, 2(4). 